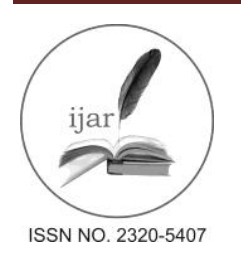

Journal homepage: http://www.journalijar.com
Journal DOI: 10.21474/IJAR01

INTERNATIONAL JOURNAL

RESEARCH ARTICLE

\title{
ENTREPRENEURSHIP AS A TOOL FOR MITIGATING 'BABY FACTORY' HUMAN TRAFFICKING IN NIGERIA.
}

Sidikat Shitu.

Directorate of General Studies, Ibrahim Badamasi Babangida University Lapai, Niger State, Nigeria.

\section{Manuscript Info}

Manuscript History:

Received: 12 February 2016

Final Accepted: 26 March 2016

Published Online: April 2016

Key words:

young women, teenage girls, humantrafficking, baby factory, entrepreneurship.

*Corresponding Author

...........................

Sidikat Shitu.

\begin{abstract}
This paper seeks to draw the attention of the academia, policy makers and human rights activists across the globe to look into the plight of teenage girls who are victims of the latest dangerous form of human trafficking, trade of infants popularly called "baby factory" in Nigeria. Human trafficking is a serious crime against humanity and the dimension is changing from time to time, especially from prostitution, forced labour, domestic servitude and begging towards the dimension at which young women, especially the teenage girls are recruited and trafficked, made pregnant, have their babies harvested and sold to adopters through illegal means. The phenomenon has shifted from the trafficking of adult and children who can communicate and talk, to the trafficking of newbornsthat are voiceless. This illegal trade is now a common phenomenon in Nigeria. It has been discovered in the South-East, South-South and South-West regions of the country. The "baby factory" kind of human trafficking is believed to be caused by high rates of poverty, loss of common shared-values, income inequality, illiteracy and unemployment. The trafficking of infants is calamitous for the image of Nigeria as a country, a threat to the fundamental human rights of Nigerians especially women and girls and sadly a threat to the future of the trafficked babies. It has become a nightmare for the parents and guardiansof the teenage girls who may not necessarily know the where about of their daughters. This paper employedthe use of secondary data by reviewing reported cases from the media and delving into the economic and social causes of the crime, its social effect on women and girls and how entrepreneurship trainingscan be used as a rehabilitating mechanism for the targets.
\end{abstract}

Copy Right, IJAR, 2016,. All rights reserved.

\section{Introduction:-}

After the successful abolition of the slave trade in the 19th Century (Ricco (2001), various nations of the world came to the realization that the sale of human beings is a crime against humanity. As the society is changing, there became more moral awakening about the fact that trafficking in human beings belittles the image of the society. Despite this, some criminally minded people across the globe still engage in the shameful trade, which is now referred to as 'modern slavery' (Amugo, 2007; Hassan, 2012.). This type of trading in human beings has placed Nigeria on the global watch list of countries known for human trafficking (Dave-Odigie, 2008). More recently, the dimension it took is even more disturbing than ever before in the sense that the phenomenon has shifted from the trafficking of adult and children who can communicate to the trafficking of innocent babies who are voiceless.

Human trafficking is believed by traffickers to be a highly lucrative business, it is perceived to be the second most lucrative criminal business in the world today, after drug trafficking (UNHCR, 2000) and also discovered to be the world's fastest growing criminal trade. It got a globally approved definition in year 2000, a definition spelt out by the United Nations Convention against Transnational Organized Crime which states that: 'Trafficking in human 
beings' shall mean the recruitment, transportation, transfer, harbouring or receipt of persons, by means of threat or use of force or other forms of coercion, of abduction, of fraud, of deception, of the abuse of power or of a position of vulnerability or of the giving or receiving of payments or benefits to achieve the consent of a person having control over another person, for the purpose of exploitation. Exploitation shall include, at a minimum, the exploitation of the prostitution of others or other forms of sexual exploitation, forced labour or services, slavery or practices similar to slavery, servitude or the removal of organs" (United Nations 2000).

\section{Anti-Trafficking Instruments in Nigeria:-}

Nigeria is the lead country in the continent of Africa known for human trafficking both domestically and internationally. The country is seen to be the origin or source, transit, and destination country for human trafficking (Olagbegi et al., 2006). Despite the fact that It is clearly stated in (section 34, 35, 41 and 46) of the Nigerian constitution that trafficking in human beings is strictly prohibited. Despite these provisions, criminally minded people still continue to engage in the shameful trade. The provision in the constitution is basically to safeguard and guarantee the fundamental human rights and dignity of every person in Nigeria, so that people can move freely and have personal freedom also it prohibits subjecting anyone to slavery or servitude, torture and inhuman or degrading treatment and forced labour. Which, if violated is enforceable in the court of law.

Going by history, Nigeria is a signatory to many international treaties, conventions and agreements, seeking to prohibit human trafficking such as the United Nations Slavery Convention 1927, ILO Forced Labour Convention, 1930, Convention for the suppression of trafficking in Persons and of the Exploitation of the Prostitution of Others 1949, ILO Abolition of Forced Labour Convention 1957, ILO Worst Forms of Child Labour Convention, 1999. With the most recent as the Palermo protocol opened to all states on $12^{\text {th }}-15^{\text {th }}$ December, 2000 in Italy and 12 th December, 2002 in New York, which is a supplementary protocol of the United Nations Convention Against Transnational Organized Crime designed to Prevent, Suppress and Punish anyone found Trafficking in Persons, especially women and children and Nigeria successfully ratified it in 2001.

In Nigeria, the phenomenon of trafficking in human beings prohibition gained a stronger ground after the ratification of the UN protocol in 2001 which eventually led to the passage of the "Trafficking in Persons (Prohibition) Law Enforcement and Administration Act" of 2003. The government and non-governmental organizations in the past two decades intensified more efforts and took very drastic measures in intervening into the phenomenon of human trafficking, which happens to be a very common trend domestically within Nigeria and beyond. Previously the most common types of human trafficking in Nigeria is trafficking in women for sexual exploitation, trafficking for forced labour as (domestic help and cheap labour), commercial sexual exploitation in and outside brothels, trafficking in human body parts for 'rituals' and organizedbegging. But recently it has taken a more complex dimension with kidnapping of people for ransom and sale of infants 'baby factory'. At the moment, no empirical study on baby factory has been carried out. The available published literature relied heavily on media reports as it is still very difficult to track down the victims involved for interviewing because of the sensitive and complex nature of the phenomenon which is characterized by secrecy.

It should be noted that for the past two decades Nigeria is increasingly witnessing various forms of human trafficking, which affect women and children, prominent among them is sexual exploitation and domestic servitude which is done in most parts of the country. Trafficked women and girls who fall victims are used locally, across borders and to other continents especially Europe. The incidence of baby factory has posed a great problem for the image of Nigeria in totality. In 2003, the Nigerian government through the national assembly passed into law the trafficking prohibition law and established the National Agency for Prohibition of Traffic in Persons and Other Related Matters (NAPTIP) and at the same time power was given to NAPTIP to arrest and prosecute anyone found wanting in any case of human trafficking. Since then NAPTIP has been working closely with the Nigeria Immigration Service, Nigeria Police Force and Foreign Embassies in Nigeria to curb the incidence of internal and trans-border human trafficking. One of NAPTIP's core responsibilities is to carry out research, create awareness of human trafficking and also engage in counseling and rehabilitation of trafficked persons.

In more recent times Nigeria is reported by various print media to be at the center of the shameful trade. Since 2006 , more discoveries have been made and reported in the media (Huntley, 2013). This situation has made the women's rights activists, such as theconcerned mothers from the South-Eastern part of the country under the aegis of OgbakoNdiNne rise up against the trend by amplifying their voices to campaign against the shameful trading of babies. 


\section{Purpose of this article:-}

The main aim of this paper is to draw the attention of the academia, policy makers and human rights activists across the globe to look into the plight of young girls who are victims of the latest dangerous form of human trafficking, sale of infants popularly called "baby factory" in Nigeria. Also, it aims at giving a picture of what the phenomenon looks like and to delve into the socioeconomic causes of the crime, how it affect younger girls and how to combat it using entrepreneurship as a tool.

\section{Methodology:-}

Given the secretive, sensitive and complex nature of the 'baby factory' phenomenon, and the unexplored nature of the trend by researchers. It is still quite very difficult to meet one on one with the young girls who were victimsof the illicit trade and whose babies were sold to illegal adopters by the owners of the baby factories. Due to the scarcity of literature on the baby factory phenomenon this paper relied heavily onsecondary data.Media reports, documentaries and published case studies were reviewed to gain an understanding of the discoveries made by the law enforcement agents and the views of Nigerians on the baby factory menace.

\section{"Baby Factory" Human Trafficking:-}

The baby factory phenomenon occurs in the context of a society with continuous increase in population, high poverty and unemployment rates. According to CIA World Fact Book, Nigeria's population was about 175million in 2013. The country has 36 states with 6 geo-political zones. Though, what is not so clear is that the baby factory human trafficking, could be happening all over the country, but so far it has been discovered in three geopolitical zones of the country (South-east, South-south and South-west). This business is done secretly in residential areas (private homes) sometimes buildings registered as food processing factories with business names and sometimes as nursing homes, clinics and NGOs. This disguise is likely to be as a result of the fact that the traffickers are aware that the Nigerian government has zero tolerance for human trafficking as the constitution clearly criminalize any form of human trafficking.

In 2006 UNESCO carried out a study in three West African states, namely Benin Republic, Togo and Nigeria on human trafficking, focusing specifically on women and children. The study was spearheaded by BisiOlateruOlagbegi of Women's Consortium of Nigeria (WOCON). The researchers discovered and reported the case of "baby harvesting" in Nigeria. At that time it was only discovered in three states, two in the southeast ( Abia and Ebonyi) and one in southwest (Lagos). In the policy paper it was revealed that the pregnant women and girls who do not want to keep their babies after delivery find their ways to meet with traffickers who disguise as genuine doctors and nurses who manage clinics, orphanages, maternity homes along with other collaborators who are involved in the illicit trade. This group of people provided the women with care for the period when they are in custody of the traffickers in which as soon as the babies are delivered the babies are sold off and the mothers are made to sign documents that disclaim their ownership of the babies and paid compensation. These women do not even know the buyers and no one could ascertain what the trafficked babies are used for afterwards.

However, academic literature on this latest trend in human trafficking 'baby factory' is extremely scarce ( Huntley, 2013) it should be noted that this is a new area of discuss in the academic arena. Evidence has shown that the facilities used as baby factories are in most cases discovered by community members who suspect and report to the police who raid the alleged factories and find that most of the allegations are true. The dimension, at which this ugly trade is taking, represents a violation of the fundamental human rights of the trafficked babies and mothers as reported by the media. The strategy for recruiting the pregnant women and girls into the baby factories is that of deceit by the owners of the factories by taking the advantage of the helplessness and powerlessness of the young girls. Also, peer influence have contributed a lot because some the girls interviewed by the media have been heard to have confirmed that their friends and family members introduced them to the baby factories after being rejected by their parents and 'boyfriends' who impregnated them and denied the pregnancy.

One fundamental thing to note is that Nigeria society detests having girls pregnant out of wedlock (it is considered as a taboo in most cultures) and when it happens, it comes with a lot of stigma on the image of the girl's family. Evidences have also emerged from the media reports that not all the girls recruited at the baby factories came there pregnant for some of the girls the traffickers make arrangement with strange men to impregnate the girls and they are kept under 'lock and key' with care until they put to bed and get their babies sold to unknown buyers who are suspected to be couples who are unable to conceive and have their own biological children. 


\section{Evidence from Documentaries and Published Reports:-}

The phenomenon was first reported in 2006, but became rampant in 2011 and since then, the Nigeria Police force has rescued about 125 young women who are victims of baby factory traffickers. In May 2011, 32 pregnant young girls wererescued by the Nigerian police in Abia State Nigeria. Also in the same year 17 pregnant girls were rescued from a purported table water factory in Imo state Southeast Nigeria ( Bakare 2014). In august 2014, the Nigerian police discovered a baby factory in Akute district of Ogun state Southwest Nigeria, the suspected operator was arrested and eight girls were freed, it was discovered that most of the girls rescued are still in their teenage age, the girls confirmed to the law enforcement agency that their babies were sold for between $\$ 1,800$ and $\$ 2,000$ which is estimated to be about 300,000 Nigerian naira in which higher prices are accorded to male children and female children are sold for lesser prices (News 24, culled from The Guardian, 2014).

In march 2014, the police raided a home in Owerri, Imo state Southeast Nigeria, where 16 pregnant girls of ages between 14 and 19 years were rescued by the Nigeria police Force, the owner of the home, had registered the home as a Non-governmental Organization with focus on women and girls empowerment. He was arrested, a shotgun was found in his possession. The girls disclosed that a sum of 100,000 Nigerian naira equivalent to $\$ 632$ was paid to them in advance and at the time of discovery a newly delivered baby was missing in the alleged 'home' already ( THEWORLDPOST, 2014). Also in Enugu State, a Maternity Clinic owned by a "Doctor" which is suspected to be a baby factory was raided severally and evidences showed that the clinic is actually a baby factory, the owner was arrested and released on bail (Agence France Presse , 2013).

According to another report by BBC Africa, seventeen pregnant teenage girls and eleven babies were rescuedfrom a house in Imo state where all the pregnant girls were impregnated by a 23years old man, who was arrested by the police (BBC, 2013). In another media report, the Nigerian Security and Civil Defense Corps (NSCDC) arrested 18 fake operators of children's Medical Clinic in IkotAkpan-Abia in the outskirt of Uyo, Akwalbom state and recovered 3children, also 18 girls were arrested at NdokiAbia State and Oyigbo in Rivers state where the pregnant girls were kept in different locations In April 2014, the police rescued five babies, three pregnant women from a baby factory in Abeokuta, Ogun State Southwest Nigeria. The baby factory was discovered by the community people who claimed the building is also suspected to be used as ritualden and reported the case to the police (Nigerian Monitor, 2014)

\section{Root Causes of Human Trafficking in Nigeria:-}

The root cause of this menace can be traced to poverty, unemployment, peer influence and social stigma. All these factors have leftwomen and girls to become vulnerable and consequently they become victims of baby factory human trafficking. The most prominent among these factors is poverty.

\section{Poverty:-}

Nigeria is rich in both human and natural resources. But regardless of all these potentials Nigeria still has millions of poor people. The problem of Nigeria is rooted in the political economy of oil and as such the economy is mired by a lot of difficulties socially, economically and politically. Thus poverty, in both absolute and relative terms, constitutes one of the most dangerous problems confronting Nigeria. 54\% of Nigerians are reported to live in poverty (British Council, 2012). The severity of poverty is prominent in the rural areas (IFAD, 2010). In the rural areas $80 \%$ of the people live below the poverty line and have no access to their basic needs. In general, women in Nigeria constitute about $49.36 \%$ of the total population (NBS, 2011). It is a clear fact that 80.2 million of Nigeria's population are women and girls and they are the most vulnerable when it comes to human trafficking.

As at 2012, the Nigeria Bureau of statistics (NBS) provided series of information that pointed to the fact that about 100 million people are living below the poverty line with less than $\$ 1.00$ (about $N 160$ ) per day for survival. This in fact is the driving force of the mangled economic and social systems of the nation. It should be noted that this state of uneven distribution of income. This abnormal poor state has further ignited a situation where income inequality increases. The gap between the rich and the poor in the country is very wide, the rich are getting richer and the poor are getting poorer. This situation forced rural dwellers to migrate to urban areas so as to bridge the poverty gap and consequently rural-urban migrations have negative impacts on the society.

\section{Peer Influence and Social Stigma:-}

Stigmatization of women and girls who have babies out of wedlock is very prominent and as such it contributes a great deal to the baby factory menace (Huntley, 2013). Young girls with unwanted pregnancies prefer to speak to their peers about their problems than speaking to reasonable adults about their problems and they end up as victims of social vices due to the fact that the society is changing and young people prefers to listen to their peers than seek help from genuine source. In the process they fall victims of trafficking among other social challenges. Evidence has 
also shown that some of the girls come to the baby factories not pregnant, but are being forced to become pregnant for the monetary benefit of the shameful trade.

\section{Recommendations and Conclusion:-}

One of the promising measures to curb or combat the baby factory menace is through entrepreneurship development. According to the Global Business School Network (2013) entrepreneurship is perceived as a vital tool which is essential in dealing with issues related to poverty, as it creates jobs, create opportunities for innovative thinking which can lead to new, small and manageable companies. Moore and Buttner (1997) suggest that entrepreneurship could increase women's self-esteem and as such should be seen as a powerful instrument for poverty alleviation and a tool for creating a better society. This requires holistic response by the Federal, State and Local Governments, NonGovernmental Organizations and the Private sector through social responsibility as a means of giving back to the society to effectively combat this menace. In doing this,effort should be geared towards human capital development by creating employment opportunities, innovative knowledge and skills especially at the grassroots for both inschool and out-of-school youths.

The baby factory trade in all ramifications should be perceived as a violation of women and children's human rights and as such should be regarded as a serious crime against humanity. In this regard, there should be massive orientation and reorientation. Nigeria government and the international organizations need to declare 'baby factory' as a serious crime against humanity. Therefore, it is also required that there should be rehabilitative support for the victims of this trade. I call on researchers and human rights activists to carry out more detailed investigations into this trend. I therefore, refer the readers to published reports in the Nigerian print media and YouTube for more details on the baby factory phenomenon.

\section{References:-}

1. Amugo, I.M (2007, June). "NAPTIP and the law'. Paper presented at the Distinguished Lecture series organized by Defence/Intelligence Agency (DIA), Abuja in June, 2007.

Council, B. (2012). Gender in Nigeria report 2012: Improving the lives of girls and women in Nigeria, issues, policies, action.

2. Dave-Odigie, C.P (2008). "Human trafficking trends in Nigeria and strategies for combating the crime". Peace Studies Journal, 1 (1), pp 63-70.

Hassan M. (2012). "Curbing the menace of human trafficking', See http://pmnewsnigeria.com/2012/02/23/curbing-themenace-of-human-trafficking-mamud-hassan/.

IFAD 2011: Rural Poverty Report.

3. IFAD Rural Poverty Report 2010.

4. Moore, D. P. \&Buttner, E. H. (1997). Women entrepreneurs: Moving beyond New Generation of Women Entrepreneurs Achieving Business Success.

5. NAPTIP, (2003). "National Policy for the Rehabilitation and Re-integration of Trafficked Victims". Federal Government of Nigeria, Abuja.

6. National Bureau of Statistic, Nigeria 2011.

7. Okogbule, N. S. (2013). Combating the "New Slavery" in Nigeria: An Appraisal of Legal and Policy Responses to Human Trafficking. Journal of African Law,57(01), 57-80.

8. Olagbegi, B. O., Aminu, L. S., Akiode, B. A., \&Zacharia, Y. (2006). Human trafficking in Nigeria: Root causes and recommendations.

9. Protocol to prevent, suppress and punish trafficking in persons, especially women and children, supplementing the United Nations convention against transnational organized crime. 2002.

10. Ricco, V. (2001) "Modern Slavery: Human bondage in Africa, Asia and the Dominican Republic." Available at http:www.infoplease.com/spot/slavery1.html, Accessed on 06/-8-2010.

11. Svetlana S. Huntley (2013) The Phenomenon of "Baby Factories" in Nigeria as a New Trend in Human Trafficking ICD Brief 3.

12. US Department of State (2010). "Nigeria: Trafficking in persons report 2010". A publication of the United States Department of State, New York.

13. http://dailyindependentnig.com/2014/01/the-baby-factory-phenomenon/.

14. http://www.bbc.com/news/world-africa-22484318

15. http://www.huffingtonpost.com/tag/nigeria-baby-factory/

16. http://www.naptip.gov.ng/aboutus.html

17. http://www.news24.com/Africa/News/Nigerian-cops-free-girls-in-baby-factory-raid-20140322

18. http://www.nigerianmonitor.com/2014/08/16/general-overseers-wife-in-baby-factory-scandal-flees-to-usa/

19. http://www.rappler.com/world/regions/africa/53638-nigeria-police-baby-factory-raid

20. http://www.vanguardngr.com/2013/12/54-nigerian-youths-unemployed-2012/

21. https://www.cia.gov/library/publications/the-world-factbook/geos/ni.html. 